\title{
Geographical variation of thermoregulation in wild populations of Mus musculus and Mus spretus
}

\author{
A. GÓRECKI, R. MECZEVA, T. PIS, S. GERASIMOV and W. WALKOWA
}

\begin{abstract}
Górecki A., Meczeva R., Pis T., Gerasimov S. and Walkowa W. 1990. Geographical variation of thermoregulation in wild populations of Mus musculus and Mus spretus. Acta theriol. 35: $209-214$.

Thermoregulation was studied in the house mice Mus musculus (Linnaeus, 1758) from Warsaw region (Dziekanów Leśny) and from Sofia (Kostinbrod) and in Mus spretus (Lataste, 1883) from southern France (Montpellier). The thermoregulation curves obtained in these three groups of mice were significantly different. The lowest values of metabolism rates in thermoneutral zone, assumed to approximate BMR values fell in range from $30^{\circ}$ to $33^{\circ} \mathrm{C}$. The body temperature in mice subjected to $5^{\circ} \mathrm{C}$ to $30^{\circ} \mathrm{C}$ range of temperatures remained fairly similar. The lowest intensity of thermoregulation, expressed in $\%$ per ${ }^{\circ} \mathrm{C}$, was observed in $M u s$ spretus while the lowest insulation index was found in Mus musculus from Dziekanów. The results indicate certain adaptations in metabolism rate of the rodent species studied, relevant to the conditions in the habitats where rodents live.

Institute of Environmental Biology, Jagiellonian University, 30-060 Kraków, Karasia 6, Poland (AG, TP); Institute of Zoology, B. A. Sci., Bulvar Ruski 1, Sofia 1000, Bulgaria (RM, SG); Department of Vertebrate Ecology, Institute of Ecology, P. A. Sci., Dziekanów, 05-092 Lomianki, Poland (WW)
\end{abstract}

Key words: thermoregulation, metabolism rate, oxygen consumption, Mus musculus, M. spretus

\section{Introduction}

The house mouse is an ubiquitous species which forms many subspecies by crossing synanthropic forms with the original wild ones. Under favourable climatic conditions, the house mouse may return to the wild, away from human settlements (particularly on islands where predators are lacking) (Pucek 1984).

In Central Europe, two synanthropic subspecies of the house mouse occur. In the western part of the range M. musculus domesticus Rutty, 1772 is found whereas in Eastern Europe, up to Scandinavia to the north, and Elbe river to the west $-M$. musculus musculus Linnaeus, 1758. The latter is less associated with human settlements and moves easily into natural locations. The two subspecies form hybrids in the border zone of their ranges (Pucek 1984).

The mice of Mus musculus musculus from Poland and Bulgaria were obtained from similar habitats (cultivated fields close to human settlements), although still different in respect to climatic conditions e.g. average annual air temperature. In Poland it was lower $\left(7.7^{\circ} \mathrm{C}\right)$ than in Bulgaria $\left(9.7^{\circ} \mathrm{C}\right)$.

Mus spretus (Lataste, 1883) is distributed throughout Portugal and Mediterranean region (Spain, southern France, northern Africa) (Orsini et al. 1982). In southern 
France Mus spretus occurs in dry warm locations (average annual temperature $14.7^{\circ} \mathrm{C}$ ) close to salt lakes and unwatered vineyards.

The information about physiological parameters is available mainly for laboratory strains of Mus musculus (Bratke and Górecki 1968, Górecki and Krzanowska 1970, 1971). The data on wild populations of M. musculus are patchy (Pearson 1947, Mokriyevich 1966, Bashenina 1977).

The aim of this study was to determine basic physiological parameters (metabolism rate and thermoregulation) in wild representatives of genus Mus and to find if there is any geographical variation between animals living in natural habitats under remarkably different climatic conditions.

\section{Material and methods}

The study of thermoregulation and basal metabolism rate was carried out in two species of Mus: Mus musculus musculus and Mus spretus. The animals used in measurements were collected in three locations in Europe shown on the map (Fig. 1): Mus spretus (11 individuals) collected on cultivated fields near Montpellier (southern France) in October 1988. Mus musculus were captured near Warsaw, central Poland (Dziekanów Leśny locality) (13 individuals) and in Sofia region (near Kostinbrod locality) (20 individuals) - both in summer 1989. Captured mice were kept in laboratory under natural light regime, with fresh water and food (cereal grain, carrot, apple) provided ad libitum.

The measurements of metabolism rate and thermoregulation were made in a closed-system Kalabukhov-Skvortsov's respirometer (Górecki 1975). The mice were put into little metal cages $(4 \times 4 \times 7 \mathrm{~cm})$ that restricted their locomotor activity. The cages were then placed in glass chambers of 0.5 to 1 litre capacity immersed in water bath with temperature regulated to the nearest $0.2^{\circ} \mathrm{C}$. The measurements were conducted in $-5,0,5,20,30,32$, and $33^{\circ} \mathrm{C}$ ambient temperatures. Each experimental run lasting 20 minutes was

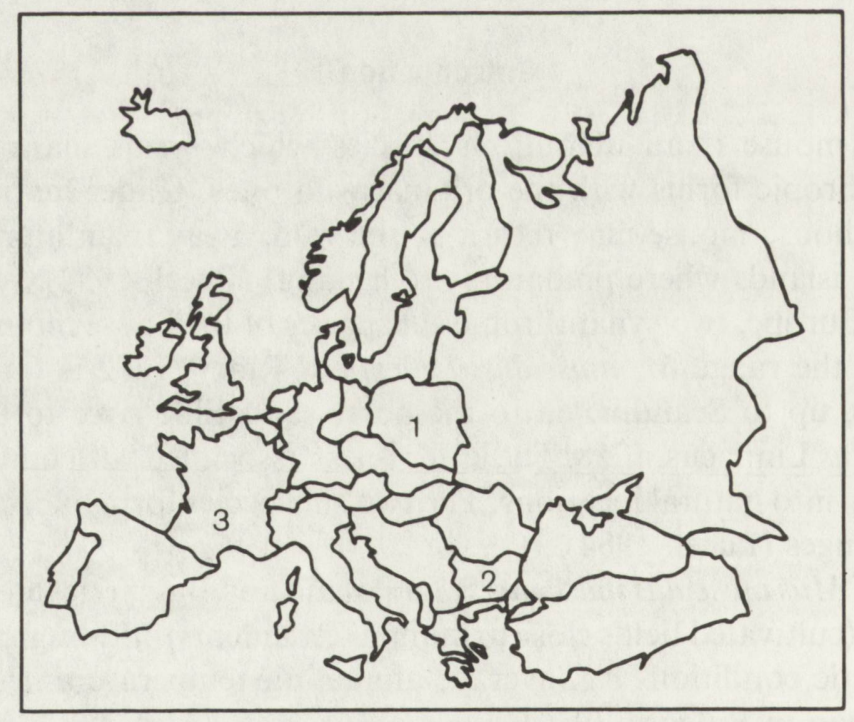

Fig. 1. Trapping sites of mice: I - Mus musculus - Dziekanów Leśny (Poland), 2-Mus musculus - Kostinbrod (Bulgaria), 3 - Mus spretus - Montpellier (France). 
preceded by acclimatization period in corresponding temperature. After the run, rectal temperature was measured in each animal at depth of about $1 \mathrm{~cm}$ by a thermistor thermometer (TL 2000) with accuracy to the nearest $0.1^{\circ} \mathrm{C}$.

All the experiments were completed at the break of September and October between 9 a.m. and 15 p.m. to avoid any effects of season and of daily metabolism cycle.

Statistical analysis used averages, SD, SE, and the regression coefficients. The comparisons were assessed by Student test (T-TEST), one factor variation analysis (ANOVA1), and covariance analysis (ANCOVA).

\section{Results}

The body weight in mice used in experiments differed significantly. The lowest body weights were noted in M. musculus from Dziekanów (average $13.2 \mathrm{~g} \pm 2.9 \mathrm{SD}$ ), the highest - in $M$. spretus $(21.8 \mathrm{~g} \pm 1.8 \mathrm{SD})$ while average body weights in Mus musculus from Kostinbrod was $18.6 \mathrm{~g} \pm 3.0 \mathrm{SD}(p<0.01$ and $p<0.05)$.

The lowest value of metabolism rate in thermoneutral zone was assumed to approximate the basal metabolism rate (BMR). In M. musculus from Dziekanów such value was obtained at $32^{\circ} \mathrm{C}\left[4.95 \mathrm{~cm}^{3} \mathrm{O}_{2} /(\mathrm{g} \times \mathrm{h}) \pm 1.07 \mathrm{SD}\right]$, in those from Kostinbrod at $30^{\circ} \mathrm{C}\left[2.64 \mathrm{~cm}^{3} \mathrm{O}_{2} /(\mathrm{g} \times \mathrm{h}) \pm 0.63 \mathrm{SD}\right]$, and in M. spretus in 32 and $33^{\circ} \mathrm{C}\left[2.84 \mathrm{~cm}^{3}\right.$ $\mathrm{O}_{2} /(\mathrm{g} \times \mathrm{h}) \pm 0.73$ and $\left.0.67 \mathrm{SD}\right]$ (Fig. 2).

The intensity of thermoregulation was calculated in $\%$ per ${ }^{\circ} \mathrm{C}$. It was lowest in $M$. spretus $\left(4.0 \%\right.$ per $\left.{ }^{\circ} \mathrm{C}\right)$ while the values for two groups of $M$. musculus were 6.3 and $7.2 \%$ per ${ }^{\circ} \mathrm{C}$ (Dziekanów, Kostinbrod).

The parameters of regression equations of thermoregulation are given in Table 1. The slope coefficients for the range of ambients used in this study differed statistically significantly from each other. The "a" coefficients in these equations differed between two groups of M. musculus and between M. spretus and M. musculus from Dziekanów.

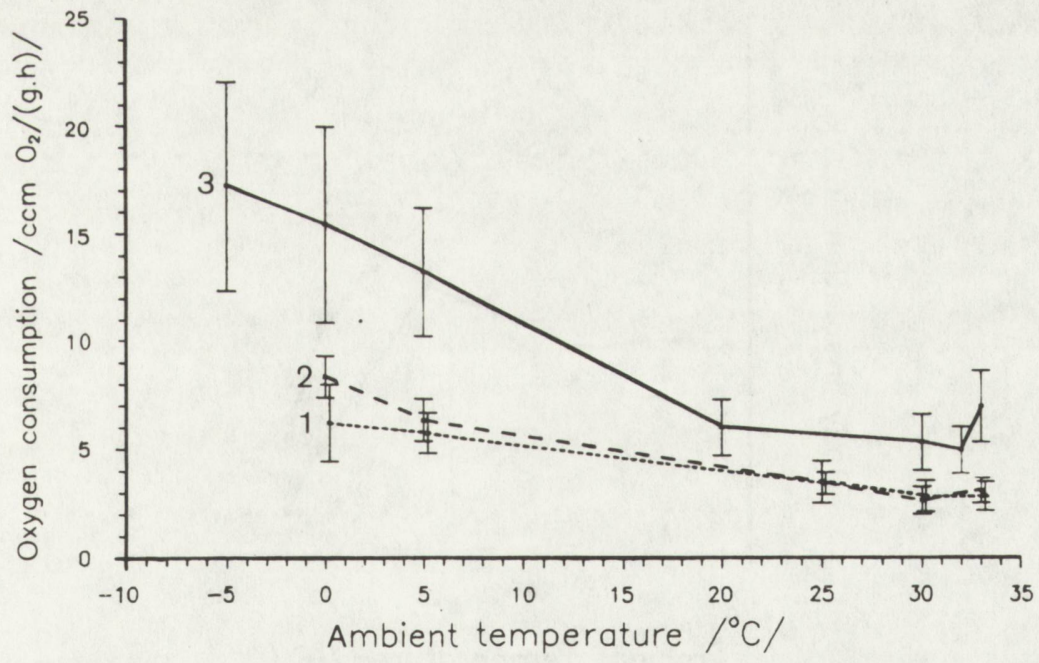

Fig. 2. Thermoregulation curves for: 1 - Mus spretus, 2 - Mus musculus from Kostinbrod, 3 - Mus musculus form Dziekanów Leśny. 
Table 1. Regressions of matabolic rate $\left[\mathrm{cm}^{3} \mathrm{O}_{2} /(\mathrm{g} \times \mathrm{h})\right]$ on ambient temperature $\left({ }^{\circ} \mathrm{C}\right)$.

\begin{tabular}{lrrrrrr}
\hline Group & $\mathrm{n}$ Intercept & Slope & $\mathrm{r}^{2}$ & $\begin{array}{c}\text { Regression } \\
\text { S E }\end{array}$ & Slope S E \\
\hline M. musculus (Dziekanów L.) & 6 & 15.06 & -0.344 & 0.96 & 2.48 & $7.01 \mathrm{E}-02$ \\
M. musculus (Kostinbrod) & 4 & 7.84 & -0.176 & 0.97 & 0.79 & $3.12 \mathrm{E}-02$ \\
M. spretus & 4 & 6.28 & -0.114 & 0.999 & $8.75 \mathrm{E}-02$ & $3.43 \mathrm{E}-03$ \\
\hline
\end{tabular}

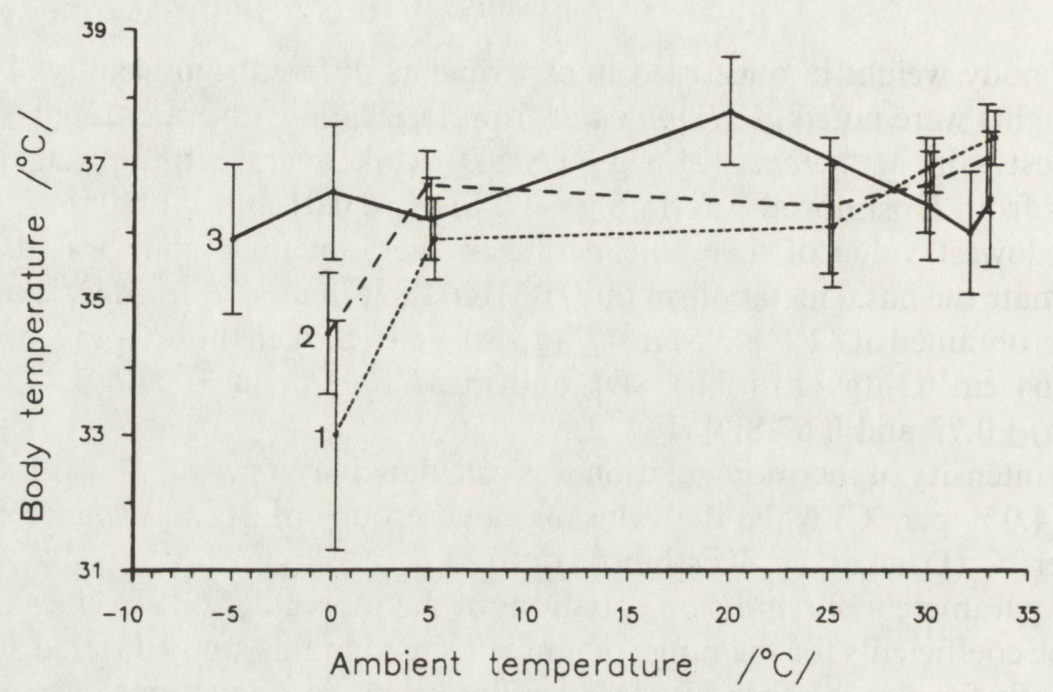

Fig. 3. Changes in rectal body temperatures at various ambients. Denotations as in Fig. 2.

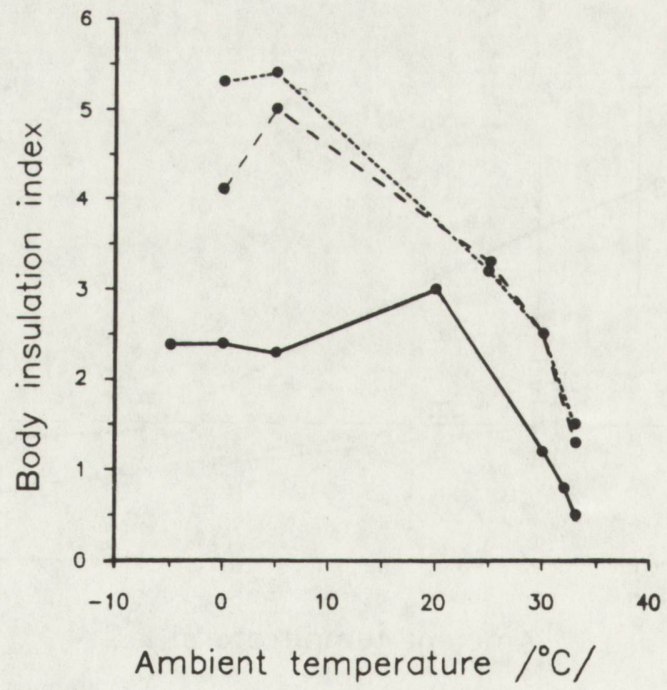

Fig. 4. Body insulation index. Denotations as in Fig. 2. 
The body temperatures determined in mice under 5 to $30^{\circ} \mathrm{C}$ temperature range did not differed significantly. In M. musculus from Kostinbrod and in M. spretus, the body temperatures drop remarkably at $0^{\circ} \mathrm{C}$, while in $M$. musculus from Dziekanów there was only a slight decrease, even at $-5^{\circ} \mathrm{C}$ (Fig. 3). In all groups, the series of measurements taken at higher temperatures showed slight elevation of body temperature.

The insulation indexes were calculated according to formula suggested by Hart and Heroux (1955) (Fig. 4). The lowest values were found in M. musculus from Dziekanów. In the remaining groups, these values were similar, with the only differences occurring at $0^{\circ} \mathrm{C}$.

\section{Discussion}

The insulation index is related to the habitat in which rodents live. Among Mus species studied, M. spretus occurs in the warmest situations. Although M. musculus from Dziekanów inhabits the area of more severe climate than that of Kostinbrod, the individuals from Dziekanów were statistically significantly smaller which, in turn, implied distinctly higher metabolism rate per unit of body weight. Since the insulation index was calculated on the basis of metabolism rate, the differences were obscured.

A metabolic adaptation phenomenon is suggested by the fact that similar values for near basal metabolic rate occur in $M$. spretus at 30 and $33^{\circ} \mathrm{C}$. In both groups of $M$. musculus the metabolism rate at $33^{\circ} \mathrm{C}$ is markedly higher (by about $30 \%$ ). According to Kondrashkin and Kuznecova (1959) and Benedict and Lee (1936) this temperature approaches the lethal temperature which, according to these authors, stands at $35^{\circ} \mathrm{C}$. The metabolic adaptation is also indicated (by a drop in body temperature at lowest ambients applied. In $M$. spretus the body temperature drops to $33^{\circ} \mathrm{C}(p<0.001)$, in M. musculus from Kostinbrod - to $34.5^{\circ} \mathrm{C}(p<0.001)$ while in smaller M. musculus from Dziekanów the decrease was not statistically significant.

The range of basal metabolism values determined in this study [from 2.6 to $4.9 \mathrm{~cm}^{3}$ $\left.\mathrm{O}_{2} /(\mathrm{g} \times \mathrm{h})\right]$ is slightly higher than those reported by Pearson (1947) and Mokriyevich (1966) and overlaps that obtained by Górecki and Krzanowska $(1970,1971)$ in laboratory strains of mice.

Laboratory mice, studied by Styrna et al. (1975) and by Górecki and Krzanowska (1971), of average body weight similar to mice from Kostinbrod, had distinctly higher intensity of thermoregulation. Laboratory mice studied by Górecki and Krzanowska (1971) whose body weight range was almost identical with that of $M$. musculus from Dziekanów had very similar shape of thermoregulation (although the range of experimental temperatures used was limited to $10-30^{\circ} \mathrm{C}$ ).

In temperatures decreasing from 30 to $5^{\circ} \mathrm{C}$, the mice from all three groups practically managed to maintain stable body temperature, while Górecki and Kania (1985) found that laboratory mice of much higher body weights (about $30 \mathrm{~g}$ ) already showed decrease in their body temperature at $10^{\circ} \mathrm{C}$.

The rectal temperature in $M$. musculus from Dziekanów determined at $20^{\circ} \mathrm{C}$ 
ambient temperature was higher by about $1{ }^{\circ} \mathrm{C}$ from relevant body temperatures in other groups. This fact is rather difficult to explain, perhaps it is associated with different "thermal experience" of these animals (which had perhaps more opportunities to spent some time within buildings in Dziekanów region which is densely built-up).

The thermoregulation curve, determined by Mokriyevich (1966) in wild Mus musculus from Volga region, showed lower values than those found in this study for any Mus. The intensity of thermoregulation calculated by this author in a slightly different manner for a $10-30^{\circ} \mathrm{C}$ range lower than that calculated in this paper for both groups of $M$. musculus, and remains very similar to that found in M. spretus.

\section{References}

Bartke A. and Górecki A. 1986. Oxygen consumption by obese yellow mice and their normal littermates. Amer. J. Physiol. 214: 1250-1252.

Bashenina N. V. 1977. Adaptivnye osobennosti teploobmena myševidnych gryzunov. Izd. Mosk. Gos. Univ., Moskva: 1-294.

Benedict F. G. and Lee R. 1936. La production de chaleur de la souris. Etude de plusieur races de souris. Ann. Physiol. 12: $33-42$.

Berry R. G. 1981. Town mouse. Country mouse: adaptation and adaptability in Mus domesticus. Mamm. Rev. 11: 3 .

Górecki A. and Krzanowska H. 1970. Oxygen consumption in two inbred mouse strains and $F_{1}$ hybrids. Bull. Acad. Pol. Sci. Cl. II, 18: 115-119.

Górecki A. and Krzanowska H. 1971. Effect of cross-foster nursing on oxygen consumption in two inbred mouse strains. Bull. Acad. Pol. Sci. Cl. II, 19: 611-615.

Górecki A. 1975. Kalabukhov-Skvortsov respirometer and resting metabolic rate measurements [In: Methods for ecological bioenergetics. W. Grodziński, R. Z. Klekowski and A. Duncan, eds]. Blackwell Sci. Publ. Oxford, London, Edinburgh, Melbourne, IBP Handbook no. 24: 309-313.

Górecki A. and Kania Z. 1986. Maximum metabolism and thermoregulation in laboratory mice. Acta theriol. 31: $97-105$.

Hart J. S. and Heroux O. 1955. Exercise and temperature regulation in lemmings and rabbits. Canad. J. Biochem. Physiol. 33: 428-435.

Kondrashkin G. A. and Kuznecova L. U. 1959. Sezonnye izmenenija ekologo-fizjologiceskih osobennostej vodianoj polevki i ejo čuvstvietelnosti k tularemii. [In: Prirodnaja očagovost' i epidemiologičeskaja osoboopasnost' infekcjonnych zabolevanij]. Saratov.

Mokriyevich N. A. 1966. Ecologico-physiological peculiarities of common voles (Microtus arvalis Pall.) and house mice (Mus musculus L.) in Volga-Ural sands. Zool. Zh. 45: 447-451. [In Russian]

Orsini F. et al. 1982. Le complex d'especes du genre Mus en Europe Central et Orientale. Reception du Mus 12: 8.

Pearson O. P. 1947. The rate of metabolism of some small mammals. Ecology 28: 127-145.

Pucek Z. (ed.) 1984. Klucz do oznaczania ssaków Polski. PWN. Warszawa: 1-388.

Styrna J., Marchlewska-Koj A. and Górecki A. 1975. The function of thyroid and oxygen consumption in mice with the gene Mosaic (Ms.). Zwierzęta laboratoryjne 12: 3-10. [In Polish with English summ.]

Received 5 June 1990, accepted 27 February 1991. 